\title{
A Review on Performance and Emissions of Compression Ignition Engine Fueled with Ethanol- diesel Blend
}

\author{
Rajnish Kumar*, Om Prakash Chaurasia \\ Mechanical Engineering Department, National Institute of Technology, Patna, India
}

Corresponding Author Email: agrajnish@gmail.com

https://doi.org/10.18280/jesa.520214

Received: 16 January 2019

Accepted: 29 March 2019

\section{Keywords:}

alternative fuel, ethano-diesel fuel blend, performance, emission

\begin{abstract}
CI engine is an important and widely used engine in the power generation industries generally fuelled by diesel. The use of CI engine vehicles is increasing continuously day by day which in turns diesel fuel consumption and engine emissions increases. Limitation of these conventional fuel as well as continuously increasing global warming by engine emissions has motivated to researchers in the field of alternative renewable fuel source like biofuel such as biodiesel, methanol, ethanol etc. Ethanol is the most commonly researched alcoholic fuel as alternative fuel. The objective of this study is to investigate the effect of ethanol-diesel fuel blend on engine performance such as BSFC, BTE, brake power, brake torque as well as engine emission parameters such as $\mathrm{NOx}, \mathrm{CO}, \mathrm{HC}$, exhaust gas temperature etc. of a CI engine. Through this study it was found that ethanol significantly reduces $\mathrm{HC}, \mathrm{PM}, \mathrm{NOx}$ and exhaust gas temperature but slightly increases fuel consumption. Also, ethanol additive enhanced engine performance like BTE, brake power and brake torque. The outcomes of this study may help for researchers to understand the effect of ethanol addition on engine performances and emissions at different ethanol-diesel fuel blend concentration for CI engine.
\end{abstract}

\section{INTRODUCTION}

Compression-ignition (CI) engines are widely used in the fiel of power generation, transportation, automotive, industrial applications and agriculture sectors due to its high fuel energy conversion efficiency and ease of operations [1]. The existing CI engines run with conventional petroleum fuel generally diesel which derived from crude oil. However, diesel fuelled engine emits harmful pollutant like NOx, CO, THC, soot, PM and also greenhouse gases such as $\mathrm{CO}_{2}, \mathrm{CH}_{4}$ etc. These pollutants have tremendous effects on environment, human, and ozone depletion caused to global warming [2]. Additionally, continuously increasing vehicle's population around the world due to increasing population, industrialization and modern life style will probably create air pollution in the next decades. Figure 1 and Figure 2 shows the rapidly increasing vehicle population and petroleum fuel consumption in India. Increasing petroleum fuels consumption and gradually increasing engine emissions has created an interest to researchers for alternative fuels which renewable in nature, environmental friendly, energy efficient, and sustainable substitute for internal combustion engine.

Renewable energy sources like natural gas, solar energy, electricity and biofuel such as biodiesel, methanol and ethanol are the good alternative to fossil fuels which can reduce fossil fuel consumption, exhaust emissions and most important global warming [3]. Ethanol is the most suited substitute to fossil fuels because it is a liquid fuel and having many physical and chemical properties similar to the petroleum fuel. However, ethanol used rarely due to complexity in their production and its economics reason [4]. Henry Ford planned to run his first automobile on both gasoline and alcohol [5].
Ethanol is an oxygenates (oxygen-containing organic compound) which was the first alcoholic fuel to power vehicles in 1880 [6]. Ethanol is a forthcoming fuel for use in an automobile as a substitute for petroleum-based fuel. The importance of ethanol is recognized after worldwide fuel crises in 1973 [7]. The main reason for using ethanol is that it can be produced from natural resources or waste material, as compared to fossil fuel which is produced from non-renewable natural resources [8].

Aydin and Ogut [9] performed for engine emissions and performance using ethanol-biodiesel-diesel fuel blend in a single cylinder, four stroke, water cooled diesel engine at blend composition $\mathrm{D}_{100}, \mathrm{~B}_{2.5} \mathrm{M}_{2.5} \mathrm{D}_{95}, \mathrm{~B}_{5} \mathrm{M}_{5} \mathrm{D}_{90}, \mathrm{~B}_{5} \mathrm{M}_{2.5} \mathrm{D}_{92.5}$ and $\mathrm{B}_{2.5} \mathrm{M}_{5} \mathrm{D}_{92.5}$. Biodiesel was obtained from safflower seed by trans-esterification method. They obtained that the maximum engine torque was measured that for $\mathrm{B}_{5} \mathrm{M}_{2.5} \mathrm{D}_{92.5}$ fuel blend at 1100rpm. Also, specific fuel consumption increased for blended fuel as compare to neat diesel. Moreover, exhaust emissions decreased significantly for ethanolbiodiesel-diesel fuel as compare to pure diesel. Maximum CO emissions decreases by $51.28 \%$ for $\mathrm{B}_{2.5} \mathrm{M}_{5} \mathrm{D}_{92.5}$ blended fuel at 2100rpm, maximum $\mathrm{CO}_{2}$ emissions increases by $31.41 \%$ for $\mathrm{B}_{2.5} \mathrm{M}_{2.5} \mathrm{D}_{95}$ blended fuel at maximum power value and maximum $\mathrm{HC}$ emissions increases by $57.14 \%$ for $\mathrm{B}_{2.5} \mathrm{M}_{2.5} \mathrm{D}_{95}$ blended fuel at maximum power value, maximum $\mathrm{SO}_{2}$ emissions decreases by $67.1 \%$ for $\mathrm{B}_{2.5} \mathrm{M}_{5} \mathrm{D}_{92.5}$ at $1100 \mathrm{rpm}$ compared with $\mathrm{D}_{100}$.

Guarieiro et al. [10] used vegetable oil biodiesel to make diesel-ethanol biodiesel ternary blend for the emissions parameters $\mathrm{CO}, \mathrm{CO}_{2}$ and $\mathrm{NO}_{\mathrm{x}}$ by a diesel engine at different blend ratio $\mathrm{D}_{100}, \mathrm{D}_{90} \mathrm{E}_{10}, \mathrm{D}_{80} \mathrm{E}_{15} \mathrm{~B}_{5}$. It was seen that $6.9-75 \%$ and $4-85 \%$ reduction in NOx emission at 1800 and 2000rpm 
respectively, 5-24\% and 4-6\% reduction in $\mathrm{CO}_{2}$ emission at 1800 and 2000rpm respectively for ethanol-diesel blend but there were no differences found in $\mathrm{CO}$ emission.

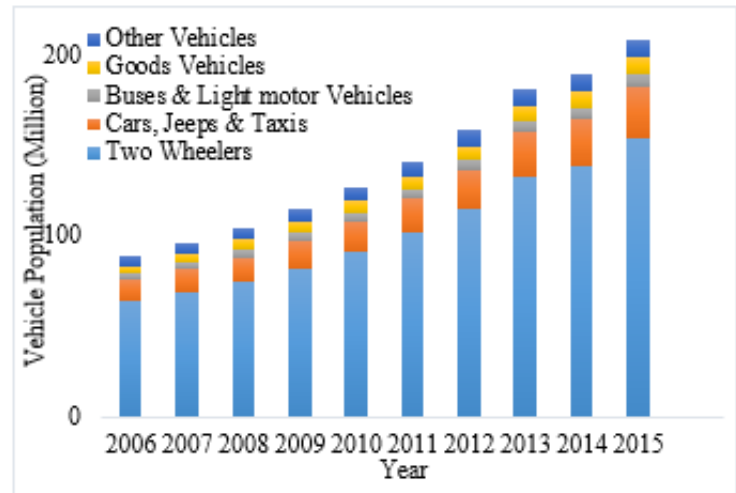

Figure 1. Vehicle population over the year from 2006 to 2015 in India (Source: MoSPI 2017 [26])

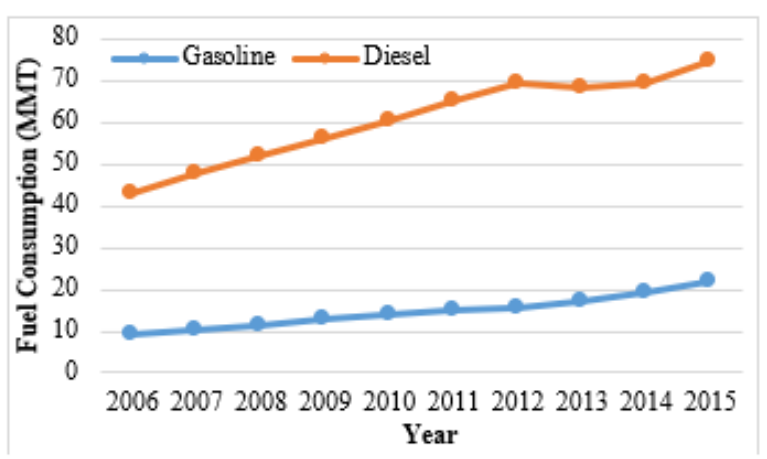

Figure 2. Fuel Consumption over the year from 2006 to 2015 in India (Source: MoPNG 2017 [27])

Eyidogan et al. [11] experimental study was carried out to test the impact of gasoline-alcohol blended fuel on the engine emissions and engine performance of four cylinder, four stroke, multipoint injection diesel engine. Ethanol (E5, E10) and methanol (M5, M10) was used as alcoholic fuel to prepare gasoline-alcohol fuel blend. They found that brake specific fuel consumption and cylinder gas pressure increased for alcohol blended fuel compared to gasoline fuel. also, exhaust gas temperature lowers in case of alcohol blended fuel and lowest heat release rate was found for pure gasoline at each vehicle speed.

Prabu et al. [12] discussed about the effect of palm oil-diesel blends on performance, combustion and emissions parameters in a single cylinder, four stroke, natural aspirated, water cooled direct injection diesel engine for $20 \%, 30 \%$ and $40 \%$ (P20, P30 and P40 respectively) palm oil-diesel blend concentration at constant speed $1500 \mathrm{rpm}$. They stated that brake specific fuel consumption and brake thermal efficiency increases by $11.4 \%$ and $5.1 \%$ for P20 fuel blend than pure diesel. CO emissions, smoke and exhaust gas temperature (EGT) decreases by $37.5 \%, 13 \%$ and $3.1 \%$ respectively whereas the $\mathrm{NO}_{\mathrm{x}}$ emissions increase for P20+diesel fuel blends. Also, it was concluded that the P20 fuel blend is the most suited blend among of other blend ratio.

Yerrennagoudaru et al. [13] demonstrated to investigate the performance and pollutant emissions of double cylinder four stroke diesel engine for fuel blend of diesel-ethanol and different biofuel at blend ratio $50 \%$ soyabean oil $+50 \%$ ethanol, $70 \%$ conola oil $+30 \%$ ethanol and $50 \%$ palm oil + $50 \%$ ethanol. The engine emissions such as $\mathrm{HC}, \mathrm{CO}, \mathrm{CO}_{2}$, smoke and Aldehyde were decreased whereas performance parameters like brake thermal efficiency and specific fuel consumption were also decreased for biofuels blend.

How et al. [14] made an experiment to investigate the effect of ethanol-biodiesel-diesel fuel blends on the engine performance, combustion and emissions parameters of a four cylinder, four stroke common-rail direct injection (CRDI) diesel engine at two different fuel blends B20 (20\% coconut biodiesel and $80 \%$ diesel) and B20E5 (20\% coconut biodiesel, $5 \%$ ethanol and $75 \%$ diesel) at a $2000 \mathrm{rpm}$ constant speed. Higher brake thermal efficiency and brake specific fuel consumption were observed for B20E5 blended fuel. $\mathrm{NO}_{\mathrm{x}}, \mathrm{CO}$ and smoke emissions lowers for ethanol-biodiesel fuel blend (B20E5) when compared to base fuel diesel.

Fernandez et al. [15] investigated a comparative analysis for performance of higher alcohol-diesel fuel blends in direct injection four stroke diesel engine. The engine was fueled with butanol-diesel (from $10 \%$ to $30 \%$ ) and pentanol-diesel (from $10 \%$ to $25 \%$ ) blends. The results showed that brake thermal efficiency increases despite of losing bake power when engine was fuled with alcohol blended fuel than neat diesel.

Another study was discussed by Hsieh et al. [16] for engine performance and exhaust emissions of a spark-ignition engine fueled with various ethanol-gasoline blend ratio $(0 \%, 5 \%$, $10 \%, 20 \%, 30 \%)$. Results were obtained that calorific value of the ethanol blended fuel decreases while the octane number increases on increasing the ethanol concentration in blends. Also, brake fuel consumption and brake torque were increased slightly; $\mathrm{HC}$ and $\mathrm{CO}$ emissions decreased rapidly whereas whereas $\mathrm{CO}_{2}$ emissions increased due to improvement in combustion because of availability of more oxygen for ethanol blended gasoline fuel instead of neat gasoline.

Hamdal and Khali [17] investigated theoretically for engine performance of a four stroke compression ignition engine fueled by diesel-ethanol and diesel-ether alternative biofuels using simulation method. Highest thermal efficiency was found when the engine was powered by $15 \%$ ethanol-diesel fuel blend and it is minimum when the engine was powered by neat diesel. Furthermore, specific fuel consumption increases with the concentration of either diesel-ethanol or diesel-ether fuel blend whereas engine brake power decreases with the concentration of either diesel-ethanol or diesel-ether fuel blend.

Padala et al. [18] carried out an experimental study of single cylinder, 4-stroke, common-rail diesel engine fueled with ethanol-diesel blends using dual-fuelling technology such that ethanol is injected into intake manifold while diesel is introduced directly in the engine cylinder. The study was focused on the effect of ethanol fraction with diesel fuel on engine efficiency and pollutant emissions at a fixed diesel injection timing. It was obtained that engine efficiency increases with increased ethanol percentage and diesel is replaced by ethanol upto $60 \%$ with $10 \%$ engine efficiency gain. The emissions like carbon monoxide, $\mathrm{NO}_{\mathrm{x}}$ and unburned hydrocarbon were increased with increasing ethanol fraction in the blend which contradict on the benefits of using ethanol in the diesel engine. However, smoke emissions were found negligible upto $20 \%$ ethanol fraction.

There are some difficulties have to be faced while trying to use ethanol blends in diesel engines. The main difficulties are:

1) Ethanol is having lower heating value as compare to diesel. Therefore, some additional fuel required than diesel by 
mass and volume [19].

2) Large amount of ethanol cannot mix with diesel duel [20]. Also, blend do not be stable for long duration of time [21].

3) Ethanol have very low cetane number as compare to diesel fuel, whereas CI engine prefer for high cetane number fuel which auto-ignite easily and lowers ignition delay period [22].

4) Diesel fuel work as a lubricant in diesel engine, whereas ethanol does not have same lubricant property [19, 21].

Ethanol can be manufactured by fermentation process from lignocellulosic materials. Examples of lignocellulosic materials are sugarcane, sorghum, corn stover, wheat strove and rice stover etc. [23]. Ethanol is having higher octane number that's why it allows for more compression ratio and it emits very less toxic in the environment as compared to petroleum-based fuel. Moreover, in the recent few years, the demand for ethanol is increased due to increasing air pollution in environment [24-25].

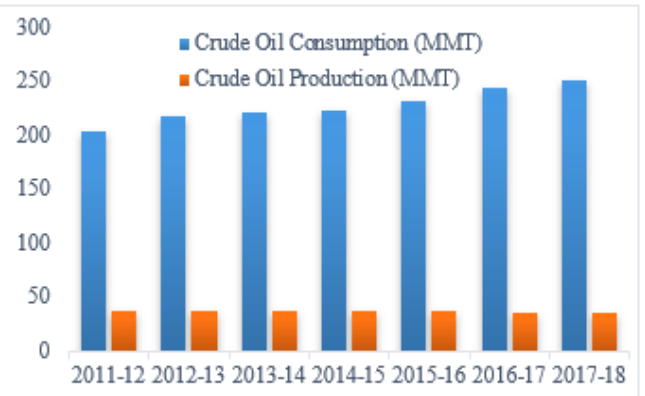

Figure 3. Crude Oil Consumption and Production in India over the year from 2011 to 2018 (Source: MoPNG 2018 [28])

\subsection{Importance of ethanol}

Fossil fuel as an IC engine fuel:

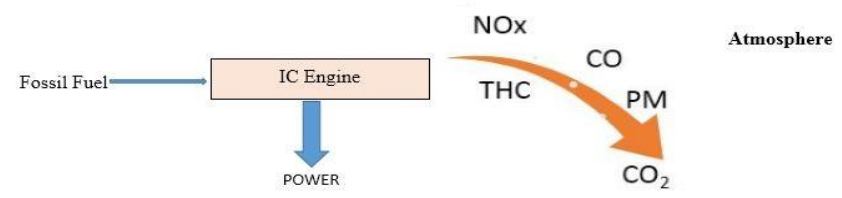

Figure 4. Engine emissions when IC engine fueled with fossil fuel

Biofuel as an IC engine fuel:

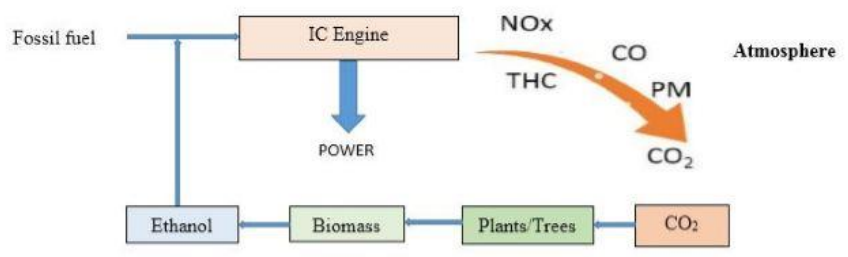

Figure 5. Engine emissions when IC engine fueled with biofuel

\subsection{Properties of ethanol for IC engine}

Ethanol is a low price oxygenate organic compound which contains oxygen that increase the oxygen content for combustion and reduce smoke and exhaust emissions [29]. Carbon $(\mathrm{C})$ and hydrogen $(\mathrm{H})$ concentration of diesel-ethanol blends reduce because $\mathrm{C}$ and $\mathrm{H}$ content of ethanol is lower than the petroleum fuels. It lowers the carbon emissions, carbon monoxide (CO) emissions, and unburned hydrocarbon (HC) emissions but reduced $\mathrm{C}$ and $\mathrm{H}$ concentration fuel blends decrease the higher specific energy of the mixture [29, 30]. Ethanol has some disadvantages such as blend stability and phase separation due to lower miscibility of mixture ethanol with its blends. Blend stability mainly depends on two factors, temperature and water content of the blend. If the temperature falls below $10{ }^{\circ} \mathrm{C}$, then these two fuels separate [31].

Table 1. Properties of diesel fuel and ethanol

\begin{tabular}{ccc}
\hline Properties & Ethanol & Diesel \\
\hline Chemical formula & $\mathrm{C}_{2} \mathrm{H}_{5} \mathrm{OH}$ & $\mathrm{C}_{12} \mathrm{H}_{26}-\mathrm{C}_{14} \mathrm{H}_{30}$ \\
Molecular weight & 46 & $170-198$ \\
Calorific value $(\mathrm{KJ} / \mathrm{Kg})$ & 26700 & 42600 \\
Octane number & $105-110$ & - \\
Cetane number & $0-5$ & 50 \\
Density $\left(\mathrm{Kg} / \mathrm{m}^{3}\right)$ & 789 & 846 \\
Latent heat of vaporization & 904 & 700 \\
(KJ/Kg) & & \\
Viscosity $(\mathrm{mPa}-\mathrm{s})$ & 1.074 & 3.546 \\
Flash Point $\left({ }^{\circ} \mathrm{C}\right)$ & 13 & 70 \\
Auto-ignition Temp $\left({ }^{\circ} \mathrm{C}\right)$ & 420 & 256 \\
Oxygen content (mass \%) & 34.78 & 0 \\
Carbon content (mass \%) & 52.17 & $84.7-84.74$ \\
Hydrogen content (mass \%) & 13.04 & $15.3-15.15$ \\
Sulfur content (Mass \%) & 0 & $<50$ \\
\hline Sources: $[29,32-35]$ & &
\end{tabular}

It can be observed from Figure 3 that a huge difference between petroleum oil consumption and production in India and it is increasing year by year. To fulfill these increasing fuel demand for transportation and industrial applications, conventional fuel should be replaced by newly developed alternative fuel like ethanol, methanol and biodiesel.

The main objective of this study is to provide a comparative overview of the literatures in the field of alternative fuel for diesel engine such as ethanol-diesel fuel blends and their consequences on engine performance parameters like BSFC, BTE, brake torque \& brake power and emissions characteristics like $\mathrm{CO}, \mathrm{CO}_{2}, \mathrm{NOx}$, unburned hydrocaron \& exhaust gas temperature of diesel engine.

The remainder of this study is planned as follows: Section 2 describes the engine performance, section 3 describes the engine emissions and section 4 shows the conclusion of this study.

\section{ENGINE PERFORMANCE}

\subsection{Brake Specific Fuel Consumption (BSFC)}

The variation of BSFC of the engine at different concentration of ethanol-diesel blended fuel for various work is shown in figure 6. BSFC is defined as the ratio of the amount of fuel consumed to brake power [36]. Rakopoulos DC et al. [37] made an experiment for six cylinder, turbocharged direct injection (DI) engine of $177 \mathrm{Kw}$ power at $1500 \mathrm{rpm}$ and 3.56 bar BMEP with $5 \%$ and $10 \%$ ethanol (by vol.) to evaluate performance and emissions level. It has been stated that BSFC increased by using ethanol blend instead of neat diesel fuel for 
same power output and it is gradually increasing with increase in amount of ethanol in blends. It indicates, the engine consumes more ethanol blended fuel than that of pure diesel [37-40]. These similar results are observed by many researchers. This expected is due to reduced calorific value of ethanol blended fuel. As shown in Table 1, the LCV of ethanol is $26.7 \mathrm{MJ} / \mathrm{Kg}$ and of diesel is $42.6 \mathrm{MJ} / \mathrm{Kg}$, so ethanol reduces the energy content of the blended fuel [41-42].

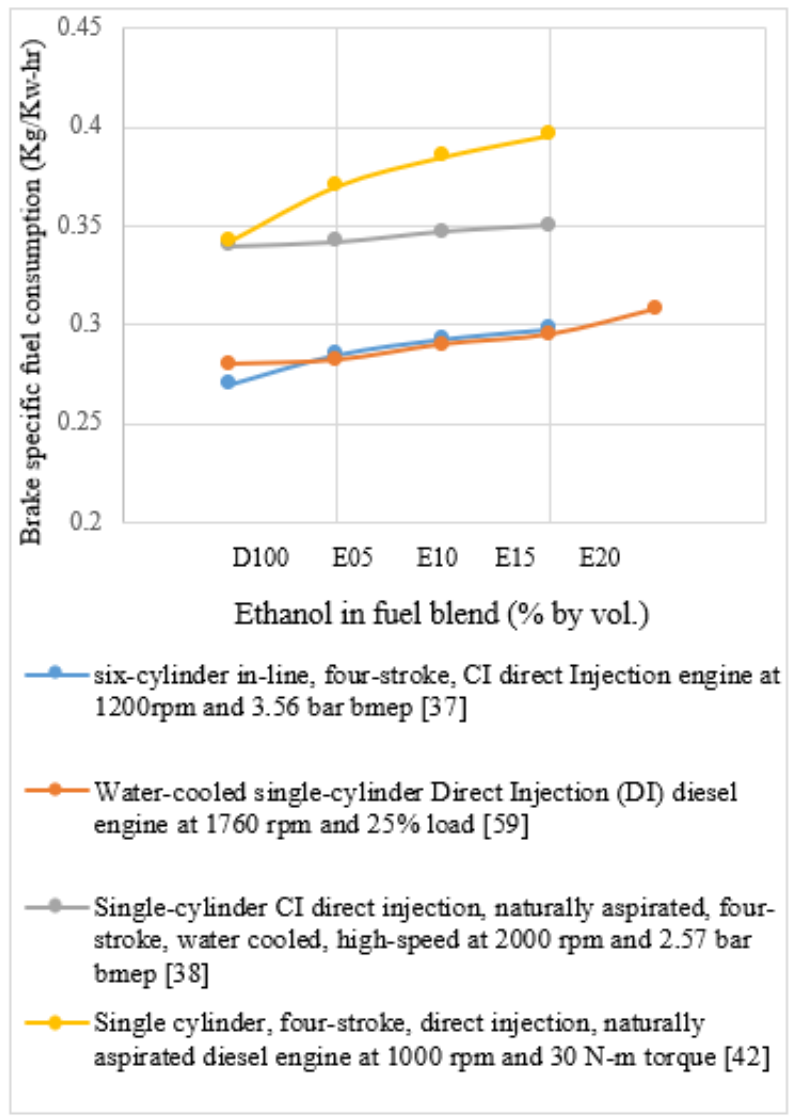

Figure 6. Variation of BSFC for various ethanol blend

Table 2. BSFC of CI engine at different ethanol blend

\begin{tabular}{cccccc}
\hline & \multicolumn{2}{l}{ BSFC $(\mathrm{Kg} / \mathrm{Kw}-\mathrm{hr})$} \\
Ref. & $\mathrm{D} 100$ & E5 & E10 & E15 & E20 \\
\cline { 2 - 6 } Rokopoulos [37] & 0.27 & 0.285 & 0.293 & 0.298 & \\
Li 2005 [59] & 0.28 & 0.282 & 0.29 & 0.295 & 0.308 \\
Rakopoulos [38] & 0.34 & 0.342 & 0.347 & 0.35 & \\
Sayin [42] & 0.342 & 0.37 & 0.385 & 0.396 & \\
\hline
\end{tabular}

\subsection{Brake Thermal Efficiency (BTE)}

BTE is the ratio of mechanical brake power produced and the fuel energy consumed by the engine in unite time. It shows the ability of conversion of fuel energy into mechanical form [5]. Figure 7 shows the variation of BTE with various concentration ethanol-diesel blended fuel. Parthasarathi et al. [41] conducted a test on a single cylinder four stroke open chamber (DI) engine at 5.2 KW power and 1500rpm constant speed fuelled with pure diesel and diesel-ethanol blend and concluded that BTE for E05 were increased and further increasing the ethanol concentration in the blend, the BTE decreased but it is still higher than pure diesel fuel. They have also observed in their study that the difference of brake thermal efficiency between base fuel diesel and blended fuel increases as the load increases. In spite of higher BSFC of ethanol-diesel fuel blends, the brake thermal efficiency of blended fuel is found higher [43]. The reason for enhancement of BTE is the increment in compression ratio due to its higher octane number in case of ethanol blended fuel [44]. Also, oxygen present in the ethanol provides better combustion efficiency causes improvement in BTE of ethanol blended fuel [45].

Table 3. BTE of CI engine at different ethanol blend

\begin{tabular}{|c|c|c|c|c|c|}
\hline \multicolumn{6}{|c|}{ BTE (\%) } \\
\hline Ref. & D100 & E5 & E10 & E15 & E20 \\
\hline Parthasarathi [41] & 28.3 & 38 & 36 & 35.1 & 34 \\
\hline Rakopoulos [37] & 38.4 & 38.9 & 39.2 & 39.6 & 40 \\
\hline Kumar R.S [58] & 26 & 23.7 & 21 & 19 & 16 \\
\hline Sayin [42] & 29.1 & 28 & 26.8 & 25.1 & 24 \\
\hline Rakopoulos [38] & 24.8 & 25.2 & 25.6 & 26.4 & \\
\hline $\mathrm{Li}[59]$ & 35 & 37 & 37.8 & 38 & \\
\hline
\end{tabular}

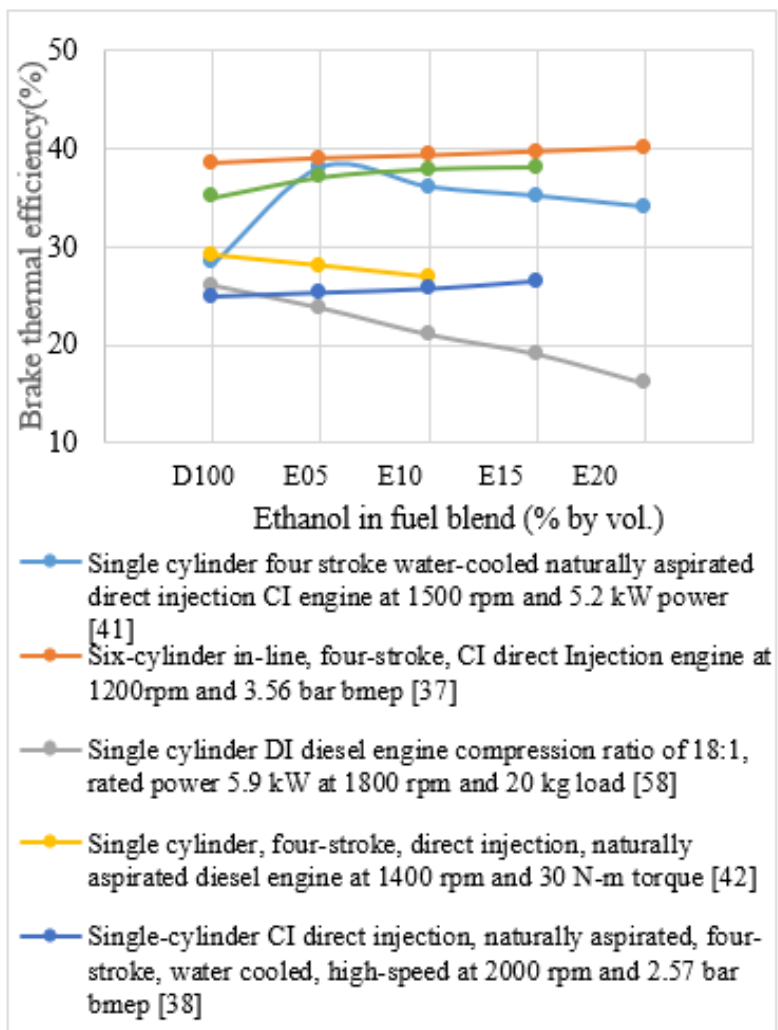

Figure 7. Variation of BTE against various ethanol blends

Furthermore, as shown in Table 1, the cetane range of diesel and ethanol is 45-50 and 5-15 respectively. So, cetane value of ethanol-diesel blended fuel reduces referred to pure diesel. Lower cetane value of blended fuel provides more ignition delay period. In this increased time period, more amount of fuel will convert into vapour causing higher heat release which indicates better efficient conversion of heat into work. Due to this reason BTE of ethanol blended fuel elevates [46]. According to Sayin [42] for a single cylinder four stroke DI engine at $30 \mathrm{~N}-\mathrm{m}$ torque and $1400 \mathrm{rpm}$ speed, the BTE reduces for ethanol blended fuel. It may occur due to reduced lower heating value (LHV) of ethanol emulsified fuel.

\subsection{Brake torque and brake power}

Brake power is proportionally dependent on the brake torque for a specified speed of the engine. Figure 8 and figure 
9 shows the effect of ethanol addition on brake torque and brake power for CI engine. Alisaraei and Rezaei [47] performed on six cylinder DI engine at $82 \mathrm{~kW}$ power $150 \mathrm{bar}$ injection pressure and $1600 \mathrm{rpm}$ and the results stated that brake torque and brake power increased with $\mathrm{E} \%$ increases at various engine speed and its maximum improvement is $3.8 \%$ at $6 \%$ ethanol fuel blend (D94E6). It occurred because of the improvement in the combustion efficiencies due to oxygenated fuel. Also, engine power depends on compression ratio and it is improved due to ethanol blending. Brake torque also depends on volumetric efficiency which increases with added ethanol concentration [47-48]. In another study, Can Ozer et al. [49] were studied the brake torque and brake power for four cylinder 4-stroke turbocharged DI diesel engine at 150bar injection pressure and $2000 \mathrm{rpm}$. They obtained that the brake torque and brake power decreased for $5 \%$ ethanol blended fuel as compare to neat diesel. Furthermore it is continuously decreases with increasing ethanol percentage in the fuel blend.

Table 4. Brake torque of CI engine for various ethanol blends

\begin{tabular}{ccccc}
\hline \multicolumn{5}{c}{ Brake torque (N-m) } \\
Ref. & D100 & E05 & E10 & E15 \\
\hline Can [49] & 140 & 125 & 110 & 102 \\
Alisaraei [47] & 190 & 210 & 205 & \\
Sandalci [53] & 24.5 & 23.8 & 23 & 22 \\
Agarwal [61] & 222 & 226 & 230 & 232 \\
Hamdam [62] & 62 & 58 & 57 & 50 \\
\hline
\end{tabular}

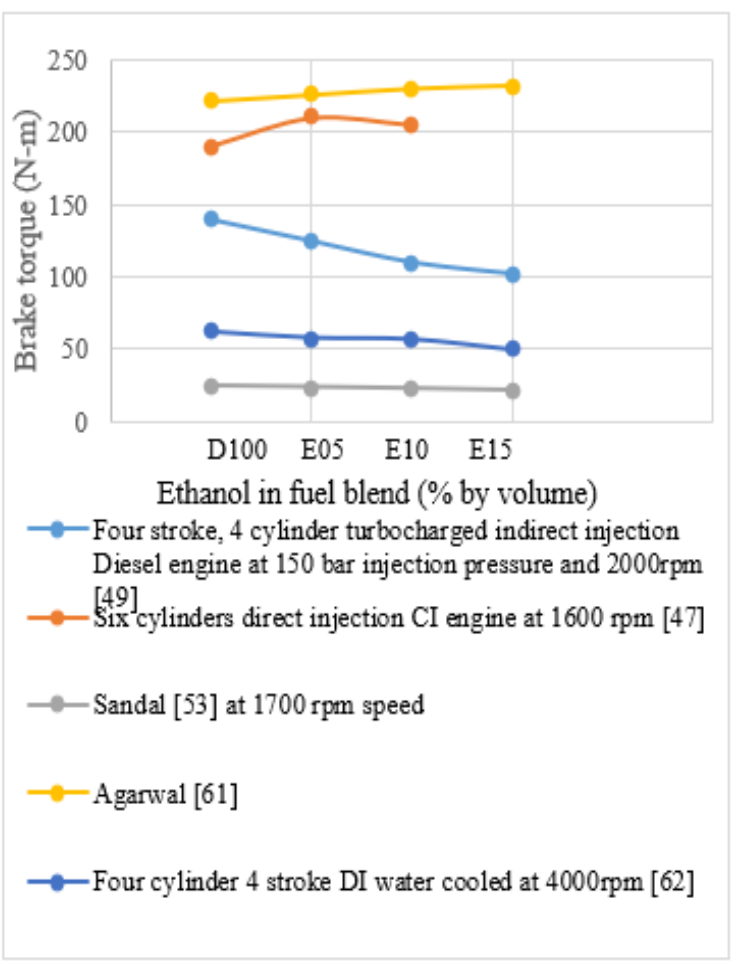

Figure 8. Variation of Brake torque with ethanol blending

Table 5. Brake power of CI engine for various ethanol blends

\begin{tabular}{ccccc}
\hline \multicolumn{3}{c}{ Brake Power (kW) } & & \\
Ref. & D100 & E05 & E10 & E15 \\
Can [49] & 28 & 25 & 22 & 20 \\
Alisaraei [47] & 39.5 & 44 & 43 & \\
Sandal [53] & 4.4 & 4.2 & 4.1 & \\
Hamdam [62] & 26 & 24 & 23 & 21 \\
\hline
\end{tabular}

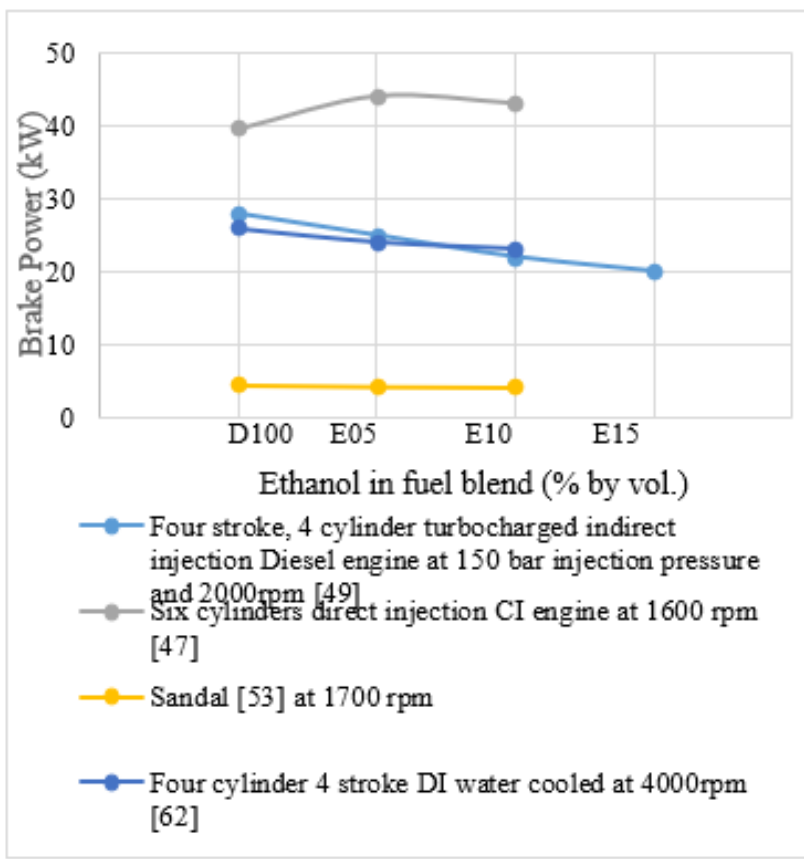

Figure 9. Variation of Brake power with ethanol blending

\section{ENGINE EMISSIONS}

Exhaust emissions such as particulate matter (PM), carbon monoxide $(\mathrm{CO})$, carbon dioxide $\left(\mathrm{CO}_{2}\right)$, oxides of nitrogen $\left(\mathrm{NO}_{\mathrm{x}}\right)$ and total unburned hydrocarbon (THC) considerably depends on oxygen content and burning condition of fuel. Donahue et al. [50] stated that engine emissions influenced by local oxygen factor of oxygenated fuel regardless of oxygen improvement method. Emissions are subjected to several aspects that make differences than caused by fuel. Some of these aspects are fuel metering method, engine maintenance, age of engine, emissions control technology and engine test condition etc. [51].

\subsection{NOx emissions}

The most worrying emissions from compression ignition engines are NOx emissions. The formation of NOx is mostly dependent on in-cylinder temperatures and the oxygen concentration [52]. Figure 10 shows that nitrogen oxide (NOx) emissions from CI engine. Parthasarathi et al. [41] performed on single cylinder 4-stroke water-cooled naturally aspirated open chamber (DI) Kirloskar TVI diesel engine at $3 \mathrm{~kW}$ BP and $1500 \mathrm{rpm}$ and reported that NOx emissions are same or slightly lower for ethanol blended fuel as that of pure diesel. According to Rakopoulos DC [37], the nitrogen oxides emissions reduced for diesel-ethanol emulsified fuel and gradually decreases with increasing percentage of ethanol in the fuel blend. Combustion temperature and oxygen content inside engine cylinder are two major reason for NOx formation [53]. This decrement of $\mathrm{NO}_{\mathrm{X}}$ emissions occurs because of temperature reducing effect of ethanol due to its lower calorific value and it is gradually decreasing with ethanol concentration. This effect is compensating by the presence of oxygen with ethanol blends. Furthermore, due to lower cetane value of ethanol blended fuel, its ignition delay period is more. So, ethanol leading to higher temperature during premixed combustion and NOx production $[4,54]$. 


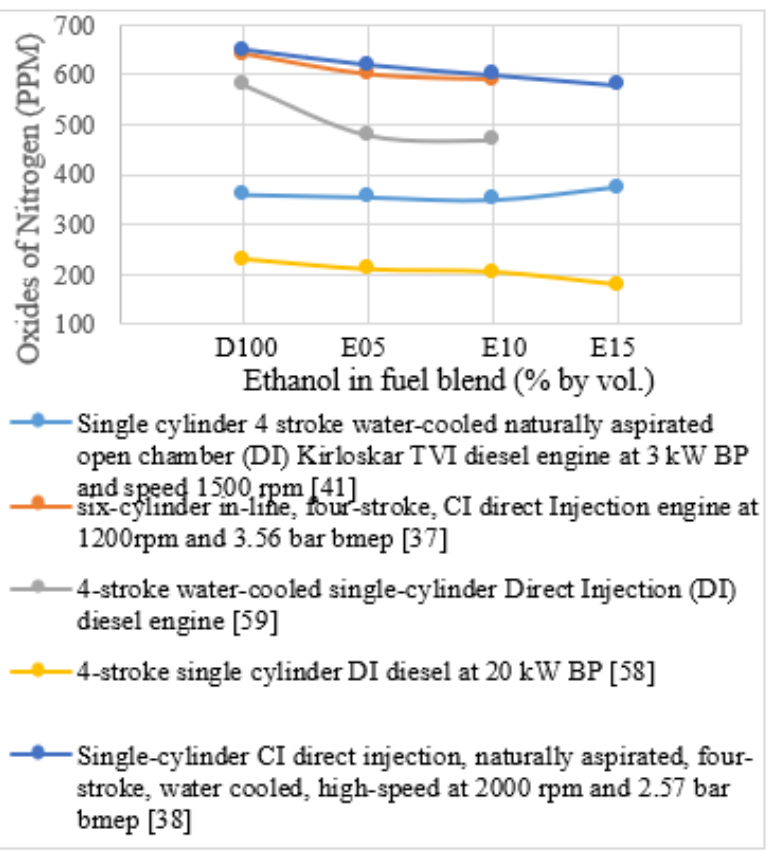

Figure 10. Effect of ethanol addition on $\mathrm{NO}_{\mathrm{x}}$ emissions

Table 6. NOx emissions from CI engine at various ethanol blends

\begin{tabular}{ccccc}
\hline & \multicolumn{3}{c}{ Nox (PPM) } & \\
Ref. & D100 & E05 & E10 & E15 \\
\cline { 2 - 5 } Parthasarathi [41] & 480 & 465 & 450 & 455 \\
Rokopoulos [37] & 820 & 810 & 800 & \\
Li [59] & 580 & 480 & 470 & \\
Kumar R.S [58] & 230 & 210 & 205 & 180 \\
Rokopoulos [38] & 650 & 620 & 600 & 580 \\
\hline
\end{tabular}

\subsection{CO emissions}

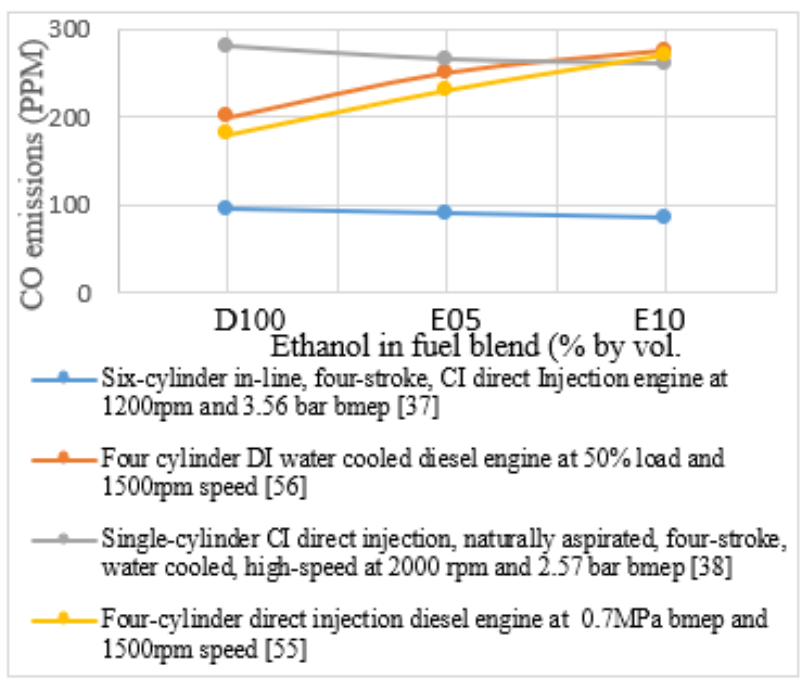

Figure 11. Effect of ethanol addition on $\mathrm{CO}$ emissions

Carbon monoxide (CO) is a toxic engine emission and it must be controlled. It forms due to incomplete combustion of the hydrocarbon fuel. Figure 11 shows the carbon monoxide (CO) emission for neat diesel's and ethanol blended fuel E05, E10 and E15. Rakopoulos DC [37] made the following observation that emitted $\mathrm{CO}$ for pure diesel fuel is higher as that of ethanol blended fuel. Increasing alcohol percentage in fuel blend would make leaner mixture of the fuel blend. So, complete combustion occurs and superior conversion of $\mathrm{CO}$ into $\mathrm{CO}_{2}$ than neat diesel fuel [38]. He at al [55] carried out an experiment for four cylinder $52 \mathrm{~kW}$ power DI engine at 245 $\mathrm{N}-\mathrm{m}$ torque and $1700 \mathrm{rpm}$ and they concluded that $\mathrm{CO}$ emission slightly increases for ethanol blend compared with diesel. Higher $\mathrm{CO}$ emissions for ethanol blends could be explained by the fact that higher latent heat of vaporization for ethanol and lower combustion temperature of the cycle [56].

Table 7. $\mathrm{CO}$ emissions from $\mathrm{CI}$ engine at various ethanol blends

\begin{tabular}{ccccc}
\hline & \multicolumn{2}{c}{ CO emissions (PPM) } & & \\
Ref. & D100 & E05 & E10 & E15 \\
\cline { 2 - 5 } Rakopoulos [37] & 68 & 58 & 45 & \\
Sun P. [56] & 200 & 250 & 275 & \\
Rakopoulos [38] & 280 & 265 & 260 & 250 \\
He B.Q [55] & 180 & 230 & 270 & \\
\hline
\end{tabular}

\subsection{HC emissions}

Hydrocarbon emission (HC) consists of the fuel which incompletely burned. Unburned hydrocarbon (HC) emissions for various fuels of different works by researchers are shown in Figure 12 and compared for fuel E0, E05, E10 and E15.

Table 8. HC emissions at various ethanol blends

\begin{tabular}{ccccc}
\hline & \multicolumn{3}{c}{ HC emissions (PPM) } & \\
Ref. & D100 & E05 & E10 & E15 \\
\cline { 2 - 5 } Parthasarathi [41] & 40 & 40 & 45 & 75 \\
Rokopoulos [37] & 12 & 13 & 13.5 & \\
Rokopoulos [38] & 62 & 64 & 76 & 82 \\
\hline
\end{tabular}

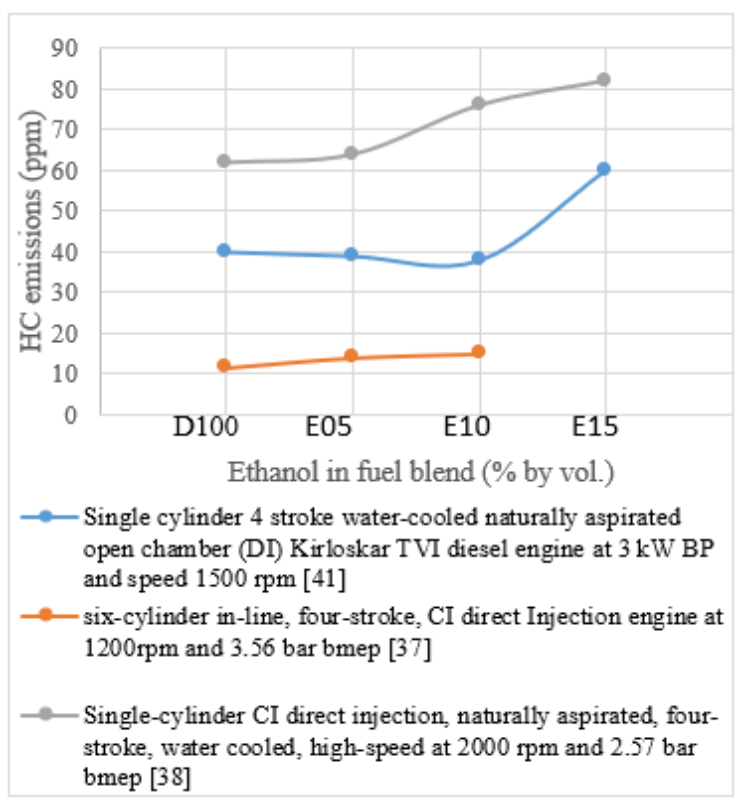

Figure 12. Effect of ethanol addition on $\mathrm{HC}$ emissions

Parthasarathi et al. [41] analyzed for emissions characteristics on 4 stroke single cylinder direct injection CI engine at $5.2 \mathrm{~kW}$ and $1500 \mathrm{rpm}$ and reported that $\mathrm{HC}$ emissions are higher for ethanol content fuel as compared to neat diesel and it were higher for higher ethanol concentration in the blend. Same behavior is concluded by almost all investigators on different types of engine and working 
conditions. Reason for enhancement in the $\mathrm{HC}$ emission is due to lower cycle temperature because of higher latent heat of vaporization of ethanol that why more fuel remains unburned as compare to diesel [57-58]. Also, it was observed that HC emission increases with increasing engine speed [59].

\subsection{Exhaust gas temperature}

Figure 13 shows the exhaust gas temperature of CI engine variation with concentration of ethanol-diesel blend. Exhaust gas temperature is an indication of combustion inside the cylinder. The results of various researchers are plotted and concluded that addition of ethanol lowers the exhaust gas temperature and continuously decreases with increasing ethanol percentage in the blend due to lower LHV of ethanol which associated with higher latent heat of evaporation [6061].

Table 9. Temperature of exhaust gas at various ethanol blend

\begin{tabular}{cccccc}
\hline \multicolumn{7}{c}{ Exhaust gas temperature $\left({ }^{\circ} \mathrm{C}\right)$} \\
Ref. & D100 & E05 & E10 & E15 & E20 \\
\hline Agarwal 2007 & 885 & 855 & 844 & 835 & 825 \\
Rakopoulos 2007 & 255 & 251 & 250 & 248 & \\
Oliveira 2016 & 424 & 423 & 417.5 & 415 & 402.5 \\
\hline
\end{tabular}

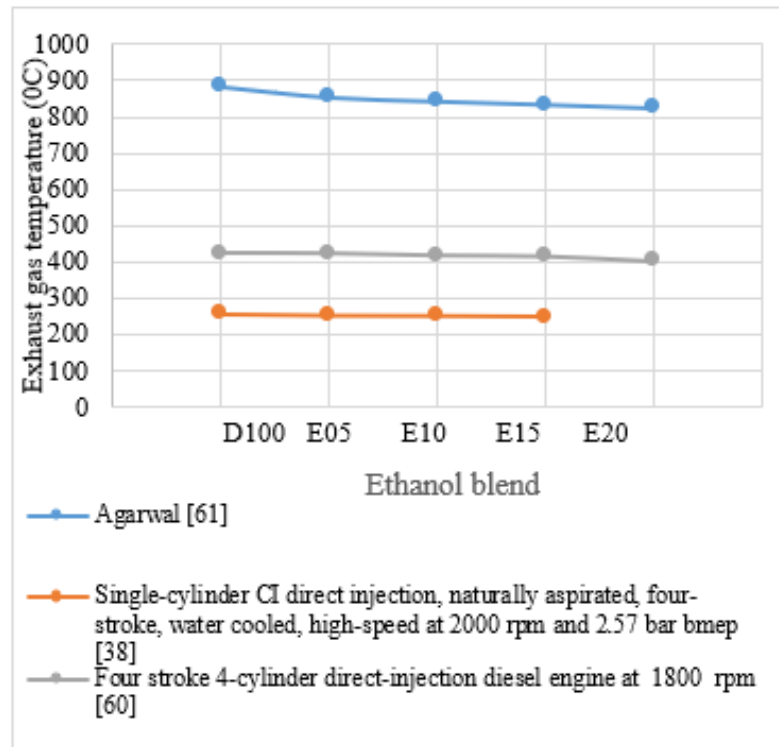

Figure 13. Effect of ethanol blend on exhaust gas temperature

\section{CONCLUSIONS}

This work described to the study and comparative analysis of ethanol-diesel fuel blend and their effect of different blend ratio on $\mathrm{BTE}$, BSFC, Brake torque, brake power and engine exhaust emissions like $\mathrm{CO}, \mathrm{HC}, \mathrm{NOx}$ and exhaust gas temperature; following conclusions can be made through the study:

1) Ethanol has shown to be alternative of fossil fuel.

2) BSFC of the ethanol-diesel fuel blend increased because of low heat content $\left(2 / 3^{\text {rd }}\right.$ as compare to diesel) of ethanol that of diesel. Also, it increases with increasing ethanol content in the blend.
3) BTE of the CI engine fueled with ethanol-diesel blended fuel improved with increasing ethanol amount of the blend. Also, brake torque and brake power of CI engine increased with ethanol-diesel blend fuel. It occurs due to the presence of oxygen in the mixture and also, improvement in ignition delay period due to reduction in cetane number with increasing ethanol quantity.

4) $\mathrm{HC}$ increased emissions while $\mathrm{CO}$ emissions decreased when $\mathrm{CI}$ engine fueled with ethanol-diesel fuel blend.

5) NOx formation of CI engine decreased with the use of ethanol-diesel fuel blend. Also, exhaust gas temperature of $\mathrm{CI}$ engine decreased and it continuously decreased with increasing ethanol blend ratio.

Further research can be extended by using different ethanoldiesel fuel blend ratio to improve engine performance with the reduction of engine emissions of diesel engine.

\section{REFERENCES}

[1] Uyumaz, A. (2018). Combustion, performance and emission characteristics of a DI diesel engine fueled with mustard oil biodiesel fuel blends at different engine loads. Fuel, 212(5): 256-67. https://doi.org/10.1016/j.fuel.2017.09.005

[2] Lopez, M.J., Gomez, A., Aparicio, F.,Sanchez, F.J. (2009). Comparison of GHG emissions from diesel, biodiesel and natural gas refuse trucks of the city of madrid. Applied Energy, 86(5): 610-15. http://dx.doi.org/10.1016/j.apenergy.2008.08.018

[3] Lif, A., Holmberg, K. (2006). Water-in-diesel emulsions and related systems. Advances in Colloid and Interface Science, 126(2): 231-39. http://dx.doi.org/10.1016/j.cis.2006.05.004

[4] Caro, P.S.D., Mouloungui, Z., Vaitilingom, G., Berge, J.C. 2001. Interest of combining an additive with dieselethanol blends for use in diesel engines. Fuel, 80: 565-74. http://dx.doi.org/10.1016/S0016-2361(00)00117-4

[5] Sward, K. (1948). The legend of Henry Ford. 1st ed. New York: Rinehart.

[6] Yuksel, F., Yuksel, B. (2004). The use of ethanolgasoline blend as a fuel in an SI engine. Renewable Energy, 29: 1181-1191. http://dx.doi.org/10.1016/j.renene.2003.11.012

[7] Daheriya, K.L., Shrivastava, N. (2012). Effect of performance and emissions on DI diesel engine using ethanol diesel blends- a review. International Journal of Engineering Research \& Technology, 1(6): 1-10.

[8] Hasan, M.A. (2003). Effect of ethanol-unleaded gasoline blends on engine performance and exhaust emission. Energy Conversion and Management, 44(9): 1547-61. https://doi.org/10.1016/S0196-8904(02)00166-8

[9] Aydin, F., Ogut, H. (2017). Effects of using ethanolbiodiesel-diesel fuel in single cylinder diesel engine to engine performance and emissions. Renewable Energy, 103: 688-694. http://dx.doi.org/10.1016/j.renene.2016.10.083

[10] Guarieiro, L.L.N., Souza, A.F., Torres, E.A., Andrade, J.B. (2009) Emission profile of 18 carbonyl compounds, $\mathrm{CO}, \mathrm{CO}_{2}$, and $\mathrm{NO}_{\mathrm{x}}$ emitted by a diesel engine fuelled with diesel and ternary blends containing diesel, ethanol 
and biodiesel or vegetable oils. Atmospheric Environment, 43: 2754-2761. http://dx.doi.org/10.1016/j.atmosenv.2009.02.036

[11] Eyidogan, M., Onsezen, A.N., Canakci, M., Turkcan, A. (2010). Impact of alcohol-gasoline fuel blends on the performance and combustion characteristics of an SI engine. Fuel, 2713-2720. http://dx.doi.org/10.1016/j.fuel.2010.01.032

[12] Prabu, S.S., Asokan, M.A., Pratibha, S., Ahmad, S., Pukhean, G. (2018). Effect of additives on performance, combustion and emission behavior of preheated palm oil/diesel blends in DI diesel engine. Renewable Energy, 122:

196-205.

https://doi.org/10.1016/j.renene.2018.01.068

[13] Yerrennagoudaru, H., Manjunatha, K., Kumar, V., Basavanagouda, D.M. (2018). Investigation and assessment of performance and emissions of an IC engine fuelled with diesel and different bio-fuels blended with Ethanol. Materials Today, 5: 6238-6246.

[14] How, H.G., Masjuki, H.H., Kalam, M.A., Teoh, Y.H. (2014). Engine performance, emission and combustion characteristics of a common-rail diesel engine fuelled with bioethanol as a fuel additive in coconut oil biodiesel blends. Energy Procedia, 61: 1655-1659. http://dx.doi.org/10.1016/j.egypro.2014.12.185

[15] Fernandez, J.C., Arnal, J.M., Gomez, J., Dorado, M.P. (2012). A comparison of performance of higher alcohols/diesel fuel blends in a diesel engine. Applied Energy, 95: 267-275 http://dx.doi.org/10.1016/j.apenergy.2012.02.051

[16] Hsieh, W.D., Chen, R.H., Wu, T.L., Lin, T.H. (2002). Engine performance and pollutant emission of an SI engine using ethanol-gasoline blended fuels. Atmospheric Environment, 36: 4030-410.

[17] Hamdan, M.A., Khalil, R.H. (2010). Simulation of compression engine powered by biofuels. Energy Conversion and Management, 51: 1714-1718. https://doi.org/10.1016/j.enconman.2009.10.037

[18] Padala, S., Woo, C., Kook, S., Hawkes, E.R. (2013). Ethanol utilisation in a diesel engine using dual-fuelling technology.

Fuel. http://dx.doi.org/10.1016/j.fuel.2013.03.049

[19] Doann, H.A. (1982). Alcohol fuels. Boulder Westview Press.

[20] Eugene, E.E., Bechtold, R.L., Timbario, T.J., McCallum, P.W. (1984). State of the art report on the use of alcohols in diesel engines, SAE Paper No. 840118.

[21] Broukhiyan, E.M.H., Lestz, S.S. (2018). Ethanol fumigation of a light duty automotive diesel engine. SAE, 9: $15-25$

[22] Radica, A. (1986). Fumigation of alcohols in a multicylinder diesel engine - evaluation of potential. SAE 860308

[23] Momayez, F., Karimi, K., Horvath, I.S. (2018). Enhancing ethanol and methane production from rice straw by pretreatment with liquid waste from biogas plant. Energy Conversion and Management, 178: 290298. http://dx.doi.org/10.1016/j.enconman.2018.10.023

[24] Prakash, T., Geo, V.E., Martin, L.J., Nagalingam, B. (2018). Effect of ternary blends of bio-ethanol, diesel and castor oil on performance, emission and combustion in a CI engine. Renewable Energy, 122: 301-9. https://doi.org/10.1016/j.renene.2018.01.070

[25] Chansauria, P., Mandloi, R.K. (2018). Effects of ethanol blends on performance of spark ignition engine-a review. Materials Today: Proceedings, 5(2): 4066-77. https://doi.org/10.1016/j.matpr.2017.11.668

[26] Ministry of statistics and programme implementation (MoSPI). (2017). Government of India motor vehicles statistical year book India. 2017.

[27] Ministry of Petroleum and Natural Gas (MoPNG). (2017). Government of India, Indian Petroleum and Natural Gas Statistics. 2016-17.

[28] Ministry of Petroleum and Natural Gas (MoPNG). (2018). Government of India, Indian Petroleum and Natural Gas Statistics. 2017-18.

[29] Fang, Q., Fang, J., Zhuang, J., Huang, Z. (2013). Effects of ethanol-diesel-biodiesel blends on combustion and emissions in premixed low temperature combustion. Applied Thermal Engineering, 54(2): 541-48. https://doi.org/10.1016/j.applthermaleng.2013.01.042

[30] Yusri, I.M., Mamat, R., Najafi, G., Razman, A., Awad, O.I., Azmi, W.H., Ishak, W.F.W., Shaiful, A.I.M. (2017). Alcohol based automotive fuels first four alcohol family in compression and spark ignition engine: A review on engine performance and exhaust emissions. Renewable and Sustainable Energy Reviews, 77: 169-181. http://dx.doi.org/10.1016/j.rser.2017.03.080

[31] Sasongko, M.N., Wijayanti, W. (2017). Effect of ethanol addition on the performance and exhaust emissions of a spark ignition engine. Journal of Mechanical Engineering and Sciences, 11(2): 2734-2742. https://doi.org/10.15282/jmes.11.2.2017.14.0248

[32] Jimenez, E.T., Svoljsak, M., Gregorc, A., Lisec, I., Dorado, M.P., Kegl, B. (2011). Physical and chemical properties of ethanol-diesel fuel blends. Fuel, 90(2): 795-802. https://doi.org/10.1016/j.fuel.2010.09.045

[33] Bernhardt, W. (1977). Future fuels and mixture preparation methods for spark ignition automobile engines. Progress Energy Combustion Science, 3: 139150. http://dx.doi.org/10.1016/0360-1285(77)90001-6

[34] Binod, P., Sindhu, R., Singhania, R.R., Vikram, S., Devi, L., Nagalakshmi, S., Kurien, N., Sukumaran, R.K., Pandey, A. (2010). Bioethanol production from rice straw: An overview. Bioresource Technology, 101(13): 4767-74. http://dx.doi.org/10.1016/j.biortech.2009.10.079

[35] Paul, A., Bose, P.K., Panua, R.S., Debroy, D. (2014). Study of performance and emission characteristics of a single cylinder CI engine using diethyl ether and ethanol blends. Journal of Energy Institute, 1-10. http://dx.doi.org/10.1016/j.joei.2014.07.001

[36] Heywood, J.B. (1988). Internal combustion engine. McGraw-Hill, Vol. 21.

[37] Rakopoulos DC, Rakopoulos CD, Kakaras EC, Giakoumis EG. (2008). Effects of ethanol-diesel fuel blends on the performance and exhaust emissions of heavy duty DI diesel engine. Energy Conversion and Management, 49(11): 3155-62. https://doi.org/10.1016/j.enconman.2008.05.023

[38] Rakopoulos, C.D., Antonopoulos, K.A., Rakopoulos, D.C. (2007). Experimental heat release analysis and emissions of a HSDI diesel engine fueled with ethanoldiesel fuel blends. Energy, 32: 1791-1808. https://doi.org/10.1016/j.energy.2007.03.005

[39] Karabektas, M., Ergen, G., Hosoz, M. (2013a). Effects of the blends containing low ratios of alternative fuels on the performance and emission characteristics of a diesel 
Engine. Fuel,

112:

$537-41$.

https://doi.org/10.1016/j.fuel.2011.04.036

[40] Huang, J., Wang, Y., Li, S., Roskilly, A.P., Yu, H., Li, H. (2009). Experimental investigation on the performance and emissions of a diesel engine fuelled with ethanoldiesel blends. Applied Thermal Engineering, 29(11-12): 2484-90. https://doi.org/10.1016/j.applthermaleng.2008.12.016

[41] Parthasarathi, R., Gowri, S., Saravanan, C.G. (2012). Experimental investigation of performance, emission and combustion characteristics of kirloskar TVI DI diesel engine using diesel-ethanol-surfactant as fuel. ARPN Journal of Engineering and Applied Sciences, 7(11): 1468-72.

[42] Sayin, C. (2010). Engine performance and exhaust gas emissions of methanol and ethanol-diesel blends. Fuel, 89(11): 3410-15. https://doi.org/10.1016/j.fuel.2010.02.017

[43] Modi, A.K.J., Gosai, D.C., Solanki, C.M. (2017). Experimental study of effect of EGR rates on NOx and smoke emission of LHR diesel engine fueled with blends of diesel and Neem biodiesel. Journal of The Institution of Engineers (India): Series C. https://doi.org/10.1007/s40032-017-0384-8

[44] Cataluna, R., Silva, R.D., Ricardo, J.C., Menezes, E.W. (2006). Effect of Ethers and Ether/ Ethanol additives on the physicochemical properties of diesel fuel and on engine tests. Fuel, 85: 815-22. https://doi.org/10.1016/j.fuel.2005.08.027

[45] Tutak, W., Lukacs, K., Szwaja, S., Bereczky, A. (2015). Alcohol-diesel fuel combustion in the compression ignition engine. Fuel, 154: 196-206. https://doi.org/10.1016/j.fuel.2015.03.071

[46] Rakopoulos, D.C., Rakopoulos, C.D., Giakoumis, E.G., Dimaratos, A.M., Kyritsis, D.C. (2010). Effects of butanol-diesel fuel blends on the performance and emissions of a high-speed DI diesel engine. Energy Conversion and Management, 51(10): 1989-97. https://doi.org/10.1016/j.enconman.2010.02.032

[47] Alisaraei, A.T., Rezaei-Asl, A. (2016). The effect of added ethanol to diesel fuel on performance, vibration, combustion and knocking of a CI engine. Fuel, 185: 718733.

[48] Chen, Z.Q., Ma, X.X., Yu, S.T., Guo, Y.N., Liu, J.S. (2009). Physical-chemical properties of ethanol-diesel blend fuel and its effect on the performance and emissions of a turbocharged diesel engine. International Journal of Automotive Technology, 10(3): 297-303. https://doi.org/10.1007/s12239

[49] Can, O., Celikten, I., Usta, N. (2004). Effects of ethanol addition on performance and emissions of a turbocharged indirect injection diesel engine running at different injection pressures. Energy Conversion and Management, 45: 2429-2440. http://dx.doi.org/10.1016/j.enconman.2003.11.024

[50] Donahue, R.J., Foster, D.E. (2000). Effects of oxygen enhancement on the emissions from a DI diesel via manipulation of fuels and combustion chamber gas composition. SAE: 724. https://doi.org/10.4271/200001-0512

[51] Meiring, P., Allan, R.S., Lyne, P.W.L. (1981). Ethanolbased multiple component fuels for diesel tractors. ASAE paper No. 81-1055.

[52] Ajav, E.A., Singh, B., Bhattacharya, T.K. (1998).
Performance of a stationary diesel engine using vaporized ethanol as supplementary fuel. Biomass and Bioenergy, 15 http://dx.doi.org/10.1016/S0961-9534(98)00055-5

[53] Sandalci, T., Karagoz, Y., Orak, E., Yuksek, L. (2014). An experimental investigation of ethanol-diesel blends on performance and exhaust emissions of diesel engines. Advances in Mechanical Engineering, 409739- 409747. http://dx.doi.org/10.1155/2014/409739

[54] Huang, Z.H., Ren, Y., Jiang, D.M., Liu, L.X., Zeng, K., Liu, B., Wang, X.B. (2006). Combustion and emission characteristics of a compression ignition engine fuelled with diesel-dimethoxy methane blends. Energy Conversion and Management, 47: 1402-15. https://doi.org/10.1016/j.enconman.2005.08.020

[55] He, B.Q., Shuai, S.J., Wang, J.X., Hong, H. (2003). The effect of ethanol blended diesel fuels on emissions from a diesel engine. Atmospheric Environment, 37(35): 4965-71. https://doi.org/10.1016/j.atmosenv.2003.08.029

[56] Sun, P., Chen, C., Ye, L., Wang, J. (2013). Study on combustion and emission of diesel engine using microemulsified ethanol-diesel fuel. Proceedings: 2013 International Conference on Materials for Renewable Energy and Environment, 1(C): 228-31. https://doi.org/10.1109/ICMREE.2013.6893654

[57] Tutak, W., Jamrozik, A., Michał, P., Sobiepański, M. (2017). A comparative study of co-combustion process of diesel-ethanol and biodiesel-ethanol blends in the direct injection diesel engine. Applied Thermal Engineering, 117: 155-63. https://doi.org/10.1016/j.applthermaleng.2017.02.029

[58] Banugopan, V., Manimaran, R., kumar, R.S. (2013). Experimental investigation on DI diesel engine fuelled by ethanol diesel blend with varying inlet air temperature. Advances in Applied Science Research, 4(1): 319-329. https://doi.org/10.1109/FAME.2010.5714809

[59] Li, D.G., Zhen, H., Xingcai, L., Zhang, W.G., Guang, Y.J. (2005). Physico-chemical properties of ethanol-diesel blend fuel and Its effect on performance and emissions of diesel engines. Renewable Energy, 30(6): 967-76. https://doi.org/10.1016/j.renene.2004.07.010

[60] Oliveira, A.D., Valente, O.S., Sodre, J.R. (2016). Performance of a diesel engine operating with blends of diesel, biodiesel and ethanol in the lower specific fuel consumption Range. SAE Technical Papers Part F1270 (October). http://dx.doi.org/10.4271/2016-36-0160

[61] Agarwal, A.K. (2007). Biofuels ( alcohols and biodiesel ) applications as fuels for internal combustion engines. Progress in Energy and Combustion Science, 33: 233-71. https://doi.org/10.1016/j.pecs.2006.08.003

[62] Hamdan, M.A., Khalil, R.H. (2010). Simulation of compression engine powered by biofuels. Energy Conversion and Management, 51: 1714-1718. https://doi.org/10.1016/j.enconman.2009.10.037

\section{NOMENCLATURE}

$\begin{array}{ll}\text { BSFC } & \text { Brake specific fuel consumption } \\ \text { BTE } & \text { Brake thermal efficiencies } \\ \text { P } & \text { Brake power } \\ \text { T } & \text { Brake torque } \\ \text { ITE } & \text { Indicated thermal efficiencies }\end{array}$




$\begin{array}{llll}\text { D } & \text { Diesel } & \text { NOx } & \text { Oxides of nitrogen } \\ \text { IMEP } & \text { Indicated mean effective pressure } & \mathrm{CO} & \text { Carbon monoxide } \\ \text { BMEP } & \text { Brake mean effective pressure } & \mathrm{HC} & \text { Unburned Hydrocarbon } \\ \text { D100 } & 100 \% \text { diesel } & \mathrm{PM} & \text { Particulate matter } \\ \text { E5 } & 95 \% \text { diesel }+5 \% \text { ethanol } & \text { THC } & \text { Total Unburned Hydrocarbon } \\ \text { E10 } & 90 \% \text { diesel }+10 \% \text { ethanol } & \mathrm{BD} & \text { Biodiesel } \\ \text { E15 } & 85 \% \text { diesel }+15 \% \text { ethanol } & \mathrm{CN} & \text { Cetane number } \\ \text { E20 } & 80 \% \text { diesel }+20 \% \text { ethanol } & \mathrm{CO}_{2} & \text { Carbon dioxides } \\ \mathrm{CA} & \text { Crank angle } & \mathrm{CI} & \text { Compression ignition }\end{array}$

